\title{
Extrahepatic Bile Duct Benign Granular Cell Tumor
}

National Cancer Institute

\section{Source}

National Cancer Institute. Extrahepatic Bile Duct Benign Granular Cell Tumor. NCI

Thesaurus. Code C5852.

A benign granular cell tumor that arises from the extrahepatic bile ducts. 